\title{
obituary
}

\section{Bruce C. Heezen}

Professor Bruce C. Heezen of the Lamont-Doherty Geological Observatory, New York, died on 21 June 1977 at the age of 53 of a heart attack while working on board the U.S. nuclear research submarine NR-1 studying the Reykjanes Ridge south of Iceland.

With his late colleague, Professor Maurice Ewing who was founder and director of the Lamont (later LamontDoherty) Geological Observatory, Bruce Heezen played a major part in the rapid post-war expansion of our understanding of the morphology and geology of the deep ocean floor, on which the now widely accepted theory of plate tectonics is based.

During the war the techniques for studying the deep ocean improved immensely so that in the early 1950s all sorts of new geological and geophysical data were being collected from the increasing number of research cruises. With Maurice Ewing, Bruce Heezen saw the enormous potential in the thorough compilation and analysis of these data, especially the morphology, on a world-wide scale. Because of the restrictive attitudes of the U.S. Navy on the publication of contour charts, he was forced to develop, with the cartographic skills of Marie Tharp, the physiographic diagram style of presentation of seabed morphology. These charts, several of which were published by the National Geographic Magazine, have been widely used by those interested in the oceans and have contributed significantly to an appreciation of what lies beneath the sea surface. His analysis of ocean floor morphology, initially of the North Atlantic and published as a Special Paper of the Geological Society of America in 1959 but later extended world-wide, became the basis of a physiographic classification used now by oceanographers, geologists and even by lawyers.

During these morphological studies in the late $1950 \mathrm{~s}$ he made what I believe to be his greatest contribution to the earth sciences. He recognised that the major ridge systems which lay roughly in the centre of many oceans were in fact linked into one continuous, although sinuous, mountain range 40,000 miles long and covering an area equal to that of all the continents combined. He found that the axis of this mid-ocean ridge system was associated with shallow seismicity and was able to predict the existence of hitherto unknown ridges southeast of Africa and across the Arctic ocean. Along the axis Heezen, and his colleagues Tharp and Ewing, noted a more or less continuous valley which was morphologically similar to and actually linked to the Red Sea and the East African rifts, and also to the tension cracks in the central Icelandic graben. It was clear that along this 40,000 mile axis the crust of the earth was under tension and splitting apart. Heezen saw this initially as evidence for an expanding earth but dropped this idea when the subduction mechanism was discovered to absorb the excess crust and global plate tectonic theory developed.

Although Heezen was able to view the oceans on a global scale, he was concerned with all scales of deep-sea geological processes. $\mathrm{He}$ recognised that far from being quiet passive regions, the abyssal deeps were disturbed by fierce and destructive turbidity currents which contributed to the cutting of submarine canyons, transported sediment great distances along the sea floor and which gave rise to abyssal plains. He was interested in all modes of sedimentation and pioneered the study of deep-sea bedforms, such as sand waves and dunes, and their relation to near-bottom ocean water movement. In his search for details of bottom processes he exploited the use of bottom photography to the full, superbly and readably presented to the general public in his book with Hollister, The Face of the Deep (1971) nominated for a U.S. National Book Award, and in the last decade he made numerous dives in research submersibles to observe the bottom directly.

Heezen was much concerned with the practical problems presented by the deep ocean. For years he advised the cable industry on the potential hazards to deep-sea cables from geological causes and much of his submersible work was directly related to naval requirements. He was an ardent supporter of international collaboration, especially the GEBCO bathymetric chart project, and pioneered the cartographic presentation of geological and tecronic data for the Commission for the Geological Map of the World.

Born in Iowa, Bruce Heezen obtained his bachelor's degree from the University of Iowa in 1948 and his Ph.D. from Columbia University in 1957. He joined Maurice Ewing in the formative stages of the Lamont Geological Observatory and spent his work- ing life there, becoming assistant professor in 1960 and associate professor in 1964. He was an enthusiastic and hard-driving seagoing scientist dedicated to using ship-time to its fullest extent. In the same way he used his time ashore to the full, often hard at work until the small hours in his rambling and paper-filled house on the Hudson River and yet never too busy to devote time to his students. Neither did he stint himself in some of the pleasures of life. He was always good for a party, beaming, boyish in appearance and heavy in build. He had a strong and provocative personality, not mincing his words when he felt strongly about an issue, and it was tragic, but perhaps inevitable, that his early collaboration with the equally strong personality of Maurice Ewing should have changed into a bitter quarrel in which both parties as well as the science suffered.

Heezen's contributions to science have been recognised by the award of the Cullum Geographical Medal and the Francis Shepard Medal for excellence in marine geology, and in June this year by the award by the American Geophysical Union of the prestigious Walter H. Bucher Medal for his life's work of "original contributions to the basic knowledge of the earth's crust."

His loss will be keenly felt by his life-long collaborator, Marie Tharp, his many colleagues, friends and students, and by the whole marine geological community who owe so much to his energetic research, his insight into the deep oceans of the world and his inspiration of his students.

A. S. Laughton

\section{Howard Hinton}

Professor Howard Everest Hinton FRS died on 2 August 1977, aged 64. $\mathrm{He}$ was one of the few remaining polymaths in the field of biology, having wide interests in many branches of the subject. However, he had a remarkable ability to become expert in any topic within a remarkably short time, so that few of his acquaintances, meeting him in connection with one facet of his interests, realised that this was not his major subject of study. Even his friends were often surprised by discovering his involvement in new fields of interest in science and the arts, as well as by his political naïvety.

Hinton was born in Mexico, and his 
reminiscences of his childhood suggested that his early education was far from conventional. It clearly did not allow him to achieve his academic potential, for he was not thought well grounded enough to enter the University of California at Berkeley, and had to content himself with admission to St José State College. However he so distinguished himself that he was soon able to transfer to the Berkeley campus. As a student he is said to have been aggressive and somewhat antisocial, with political attitudes and a concern for the underdog which, even at Berkeley, were forty years ahead of their time. Nevertheless he was clearly a brilliant student, and after taking his B.Sc. he moved to Cambridge, England to take his Ph.D. under the supervision of $\mathrm{Dr}$ A. D. Imms.

His main academic preoccupation at that time was beetle taxonomy, but his wider interests were already apparent. $\mathrm{He}$ went on scientific expeditions to his birthplace, Mexico, in 1933 and 1934, and in 1937 to Peru, Bolivia and Brazil. In 1939 he was appointed Assistant Keeper at the British Museum (Natural History) in London, first to work on what was to him the new subject of orthoptera (he soon made himself an expert) and then on the group which were still his main interest, beetles. He caused some concern to the authorities at the museum, for he was not prepared to adopt the gentlemanly working hours (10 to 5) then generally accepted. He sleptor worked-night after night in the museum during the blitz and of ten even when there were too few bombs falling to make this respectable. His scientific output was prodigious, including a 350 page monograph on the beetles affecting stored products in addition to a great many solid papers on insect taxonomy and phylogeny.

His work at that time included studies of larval lepidoptera, which led to a general interest in lepidopteran phylogeny. Some of his colleagues at the museum thought that he was devoting too much time to such studies and not to conventional taxonomy. Hinton was therefore glad to move, in 1949, to Bristol University as Reader in Zoology. This gave him greater freedom to choose his fields of study, a choice of which he made good use. He was elected FRS in 1961, to a personal Chair of Entomology in 1964, and became Professor of Zoology and head of the Department in 1970. At Bristol his best known research was his delicate work with the scanning electron microscope, with which he studied and elucidated the functional morphology of many forms of insects and their developmental processes.
Surprisingly for someone not brought up in the English countryside, Howard Hinton was an excellent field naturalist familiar with the flora and fauna of Britain. In fact he said that he derived his inspiration for his apparently esoteric laboratory work from his observations of living creatures in their natural environment. That his interests were not restricted to insects was further demonstrated by his production (with A. M. S. Dunn) of an attractive book on Mongooses.

As well as being an acute observer, a formidable synthesiser and a stimulating teacher, Hinton was an efficient and hardworking editor. He started and brought to success two major scientific periodicals, the Journal of Insect Physiology and the Journal of Insect Biochemistry. Most scientists would have felt that editing only one such publication was, in itself, a fulltime job, yet Hinton managed both without any apparent reduction in his research or other activities. From 1969-70 he was also an effective President of the Royal Entomological Society, and in 1972 of the British Entomological and Natural History Society. Even towards the end of his life, when he knew that he was unlikely to survive until the date of his projected retirement in September 1978, he continued his activities with undiminished vigour and even completed his massive, three volume, monograph on insect eggs. His work in many fields will be appreciated for many years to come.

Kenneth Mellanby

\section{Leonard Eastham}

Professor L. E. S. Eastham died on 19 July 1977 at the age of 84. Many former students remember him with gratitude and affection, for his understanding of their problems and his effective and unspectacular help. $\mathrm{He}$ came originally from Lancashire, and studied agriculture at the Harris Institute, Preston. This course was interrupted by the 1914-18 war, when he served in the Special Brigade of the Royal Engineers. After demobilisation he crossed the Pennines to Leeds, and studied zoology under Professor Walter Garstang. From 1921-27 he was lecturer in zoology at Birmingham University.

In 1927 he was appointed Lecturer in Advanced and Economic Entomology at Cambridge University. At that time Cambridge gave scant recognition to those coming from universities other than Oxford and Trinity College, Dublin (holders of provincial doctorates were officially 'Mister') and Eastham's position was, at first, not a comfortable or an easy one. I rember him saying that some of his colleagues were so anxious to show their high social status that they forgot to behave like gentlemen. However, he was soon warmly accepted by his students, particularly those taking entomology in Part 2 of the tripos. He proved an inspiring teacher; his knowledge of agriculture, in a department where few had such practical experience, made the subject live, and a number of his students went on to important work in economic entomology in many lands.

From 1932 to 1958 Eastham was Professor of Zoology at Sheffield. Before the 1939-45 war the department was tiny, with only two other academic colleagues. Except for large classes of medical and dental students (1st M.B.) the number of undergraduates was not great, but there were separate classes for intermediate, general degree and special honours students, and a heavy teaching load which would overwhelm most present-day academics. Eastham bore his full share of the teaching, always maintaining his standards. $\mathrm{He}$ ran the department efficiently with next to no secretarial help. And he continued actively in research, producing a stream of scholarly and original papers.

After the war, the university, and the zoology department, grew rapidly to many times its previous size. Eastham was Dean of Science, and, from 1946-50, the first Pro-ViceChancellor. These and other outside duties did not prevent him from continuing his close and valued contacts with his junior colleagues and his present and past students.

From 1946 until his retirement Eastham played an important part in the creation and development of the new universities being established throughout the British Empire. In 1946 he was a member of a party under Sir Wiliam Hamilton Fyfe's chairmanship which visited West Africa and selected the site for the future university of Ibadan. $\mathrm{He}$ was a member of the Inter University Council for Higher Education in the Colonies (now for 'Overseas') and its executive, and he paid many visits to the embryonic universities and served on the Council at Ibadan. His visits were always appreciated; unlike many of the 'experts' who were similarly involved he always took the trouble to learn the facts, especially when political and other troubles arose, and his shrewd but sympathetic assessment helped and encouraged those trying to establish institutions of high academic standards under difficult conditions.

Kenneth Mellanby 